\title{
The haustorium as a driving force for speciation in thallus-forming Laboulbeniomycetes
}

\author{
Danny Haelewaters ${ }^{1,2,3^{*}}$, Maarten Lubbers ${ }^{4}$ (iD and André De Kesel ${ }^{5}$ (D)
}

\begin{abstract}
Laboulbeniomycetes is a class of fungi that have obligate associations with arthropod hosts, either for dispersal (order Pyxidiophorales) or as biotrophic parasites (orders Herpomycetales and Laboulbeniales). Here, we focus on Herpomycetales and Laboulbeniales, which include fungi that form thalli, 3-dimensional, multicellular units of $1000 \mathrm{~s}$ of cells. Based on recently published data regarding patterns of speciation, we present the One-Host-One-Parasite model $(1 \mathrm{H} 1 \mathrm{P})$ for haustorial thallus-forming Laboulbeniomycetes. We hypothesize that taxa with haustoria, rhizoidal structures that make contact with the host's body cavity, have very strict host specificity. For taxa without haustoria, the microhabitat-as selected by the host-governs host shifting, presence or absence of the fungus, abundance, effective host range, and geographic distribution. We make suggestions for future research including fluorescent labeling of waxy lipids and mass spectrometry. These techniques have the potential to generate the data necessary to evaluate the here proposed 1H1P hypothesis for Herpomycetales and Laboulbeniales.
\end{abstract}

Keywords: Ectoparasitic fungi, Haustorium, Herpomyces, Host specificity, Integrative taxonomy, Laboulbeniales, OneHost-One-Parasite

\section{THALLUS-FORMING LABOULBENIOMYCETES}

Fungi in the class Laboulbeniomycetes are obligately associated with arthropods-either for dispersal (order Pyxidiophorales) or as biotrophs (orders Herpomycetales and Laboulbeniales). Species of Pyxidiophora are characterized by a complex, three-morph life-cycle; they have one sexual morph and two independent asexual morphs (Lundqvist 1980; Blackwell et al. 1986a, 1986b; Blackwell and Malloch 1989; Kirschner 2003; Jacobs et al. 2005). Taxa in Herpomycetales and Laboulbeniales differ from other fungi in their non-hyphal multicellular units of up to several thousand cells, or thalli, which are directly formed from two-celled ascospores (Thaxter 1896;

*Correspondence: danny.haelewaters@gmail.com

${ }^{1}$ Faculty of Science, University of South Bohemia, Branisovska 31, 350 07 České Budějovice, Czech Republic

Full list of author information is available at the end of the article
Benjamin 1971; Tavares 1985; Haelewaters et al. 2019b). These thalli are characterized by determinate growth. No asexual morphs are known in these orders. Species descriptions in thallus-forming Laboulbeniomycetes have been traditionally based on morphological features, but recent work has shown that the morphological species concept (sensu de Queiroz 1998, 2007) does not always hold to the phylogenetic (or unified) species concept (Haelewaters et al. 2018, 2019c; Haelewaters and Pfister 2019).

\section{PATTERNS OF SPECIFICITY}

Laboulbeniales and Herpomycetales are unique for displaying host, habitat, and position specificity. The majority of taxa are host-specific; they occur on a certain host genus or even species (Richards and Smith 1954; De Kesel 1996a, b). However, when one species occurs on phylogenetically disparate hosts, these hosts are sympatric; they original author(s) and the source, provide a link to the Creative Commons licence, and indicate if changes were made. The images or other third party material in this article are included in the article's Creative Commons licence, unless indicated otherwise in a credit line to the material. If material is not included in the article's Creative Commons licence and your intended use is not permitted by statutory regulation or exceeds the permitted use, you will need to obtain permission directly from the copyright holder. To view a copy of this licence, visit http://creativecommons.org/licenses/by/4.0/. 
invariably occur in the same microhabitat. For example, Stichomyces conosomatis, which is specific to species of the genus Sepedophilus (Coleoptera, Staphylinidae), has been found on Speonemadus algarvensis (Coleoptera, Leiodidae) in subterranean caves where specimens of both beetle genera co-occur (Reboleira et al. 2017). During a study of ant nest inquilines-arthropods that live in ant nests and have an obligatory symbiotic relationship with the ants, Rickia wasmannii, until then considered strictly host-specific to ants of the genus Myrmica (Hymenoptera, Formicidae), was found infecting phylogenetically far-distant arthropods, mites, and a fly larva (Pfliegler et al. 2016).

Species of Laboulbeniales and Herpomyces produce sticky ascospores that are primarily transmitted through direct contact (De Kesel 1996a, b) - such as mating, grooming behavior of social insects, and intra- and inter-generational contacts in dense (overwintering) aggregations. The success of ascospores adhering to an integument and developing into a mature thallus not only depends on the characteristics of the integument but also the habitat conditions selected by the host. De Kesel (1996a, b), rearing insects on different soils in the laboratory, was able to successfully grow Laboulbenia slackensis on atypical hosts in the same conditions as preferred by its typical host, Pogonus chalceus. This discovery has pushed research on the ecology of Laboulbeniales and habitat specificity in particular, because under natural conditions $L$. slackensis is only found associated with a few strictly halobiont species of Pogonus, Pogonistes, and Syrdenus (Coleoptera, Carabidae) (Santamaría 1998). However, one host species, Cafius xantholoma (Coleoptera, Staphylinidae), which shares the coastal, wet, and saline environment of $P$. chalceus, is host to Laboulbenia littoralis. Laboulbenia littoralis and L. slackensis, are morphologically very similar, and we assume that the fungus has shifted from one host to the other as a result of host sympatry (habitat specificity), followed by divergent natural selection and reproductive isolation (De Kesel and Haelewaters 2014).

Another type of specificity goes to the extreme; certain taxa of Herpomycetales and Laboulbeniales are only found on a particular position of the host's integument; this is referred to as position specificity. For example, Herpomyces periplanetae occurs on the antennae of Periplaneta cockroaches (Blattodea, Blattidae), Chitonomyces unciger is only ever observed on the left posterior claw of male diving beetles of the genus Laccophilus (Coleoptera, Dytiscidae), and Laboulbenia hyalopoda is found exclusively on the last abdominal segment of Paradromius linearis (Coleoptera, Carabidae) (De Kesel 1998; Goldmann and Weir 2012; Wang et al. 2016). Hosts with position-specific taxa very often carry one or more other species elsewhere on their integument (Goldmann and Weir 2012). Without data from molecular phylogenetic studies, morphology-based conclusions about this type of specificity remain problematic; are all of these taxa biological species?

\section{SPECIES AND MORPHOTYPES}

Authors have followed two opposing views when describing forms based on morphology alone. One view recognizes species that are strictly position specific and/or only occur on a given sex of the host (= sex-of-host specificity). Benjamin and Shanor (1952) described six species of Laboulbenia on Bembidion grapii (Coleoptera, Carabidae), each restricted to a given position on the host. The alternative view recognizes forms that are related to host, host sex, and position on the integument, as morphotypes of given biological species. However, without molecular data and data from transmission studies (including host specificity and host shifting), it is impossible to draw limits among (1) morphologically similar thalli that have different host species, (2) morphologically different thalli on different sexes of the same host species, or (3) morphologically different thalli that occupy different positions on the same host specimen (Scheloske $1969,1976)$. This is why we have advocated an integrative approach to the taxonomy of thallus-forming Laboulbeniomycetes (Haelewaters et al. 2018, 2019a, c) - an effort that has long been adopted in many other groups of fungi (Wijayawardene 2019), including Aspergillus (Pringle et al. 2005), Cortinarius (Stefani et al. 2014), Geastrum (Accioly et al. 2019), Helvella (Skrede et al. 2017), Leptographium (Yin et al. 2019), Octospora (Sochorová et al. 2019), Ophiocordyceps (Araújo et al. 2018), Phialocephala (Grünig et al. 2008), Protoparmelia (Singh et al. 2015), and Tranzscheliella (Li et al. 2017). This push towards an integrative fungal taxonomy has been met with some resistance among laboulbeniologists faced with the impracticability of performing molecular work, who perhaps perceive it as a threat to the long-standing traditional morphology-based species descriptions. We do, however, want to emphasize the importance of alpha taxonomy (Haelewaters et al. 2021a), as generating sequences for Laboulbeniales remains challenging, especially for specimens from dried entomological collections (Weir and Blackwell 2001; Haelewaters et al. 2015; Sundberg et al. 2018a). Besides, many researchers lack access to sufficient funding or equipment to generate molecular data. These researchers are often based in tropical areas where most of the world's undescribed species are still to be found (Hawksworth and Rossman 1997; Haelewaters et al. 2021b). Because tens of thousands of Herpomycetales and Laboulbeniales taxa are still to be discovered (Weir and Hammond 1997), we advise taxonomists to 
continue working with available resources and techniques with the understanding that future molecular phylogenetic work may confirm or shift species limits by supporting or rejecting the taxonomic value of used morphological characters and their variability. We believe collaboration between fungal molecular systematists and classically trained taxonomists should be the end goal.

\section{ONE-HOST-ONE-PARASITE, OR THE HAUSTORIUM THEORY}

As we explore generalized speciation patterns of taxa in Herpomycetales and Laboulbeniales using combined morphological, molecular, and ecological data from individual thalli, we can possibly link some of these patterns to morphological or life history traits. One such candidate trait is the haustorium. This rhizoidal structure penetrates the host's integument to make contact with the haemocoel, possibly to provide additional holdfast and increase surface area for uptake of nutrients and water. Haustoria can be simple or branched, and single (in Laboulbeniales) or multiple (in Herpomycetales) per thallus. All Herpomyces species form haustoria. Benjamin (1971) thought that all Laboulbeniales formed haustoria, but recent work (Tragust et al. 2016; Reboleira et al. 2021) found no evidence for penetration in five species of ant- and millipede-associated Laboulbeniales. In fact, compared to the superficially attached Laboulbeniales, haustorial Laboulbeniales are rare and represented in only 13 of 146 described genera (Thaxter 1931; Tragust et al. 2016): Arthrorhynchus, Coreomyces, Dimeromyces, Gloeandromyces, Hesperomyces, Hydrophilomyces, Laboulbenia, Microsomyces, Moschomyces, Rhizomyces, Stigmatomyces, Trenomyces, and Thaumasiomyces. Note that in a given genus, only some species may produce haustoria, as is the case in Gloeandromyces, Laboulbenia, and Stigmatomyces. Accumulating evidence for the presence of non-haustorial taxa in Laboulbeniales challenges the idea of the group being ectoparasitic as a whole; Laboulbeniales may instead occupy several positions on the symbiosis spectrum ranging from ectobiont (that is, they are externally attached) commensals to ectoparasites. One paper even presented evidence for a mutualistic role of Laboulbeniales for their hosts, in protecting them from infection by entomopathogenic fungi (Konrad et al. 2015).

We consider that, due to the invasive nature of their haustoria, Herpomycetales and haustorial Laboulbeniales maintain close interactions with their hosts, possibly involving adaptations to the hosts' defense systems and leading to escape-and-radiate coevolution (Ehrlich and Raven 1964). This kind of coevolution involves a process of stepwise adaptation and counteradaptation; a host develops a new defense mechanism, to "escape" association with a given parasite and diversify. The given parasite can evolve new counter mechanisms, ultimately resulting in physiological adaptation. Enhanced by their exclusively sexual mode of reproduction, these developments lead to an evolutionary arms race, involving specialization and increasing reproductive isolation. This is analogous with Dobzhansky's (1946) idea emphasizing physiological aspects in Drosophila speciation. For example, Hesperomyces virescens forms a haustorium and is in fact a complex of many near-cryptic species, each with their own host (Haelewaters et al. 2018). In contrast, Rickia wasmannii does not form a haustorium and is a single phylogenetic species with different Myrmica hosts that are placed in phylogenetically unrelated species groups (Haelewaters et al. 2019a). Both examples provide support for the haustorium theory (Fig. 1).

We propose the One-Host-One-Parasite (1H1P) model, with Hesperomyces as prime example (Haelewaters and De Kesel 2020). We hypothesize that the presence or absence of haustoria determines speciation in thallus-forming Laboulbeniomycetes. In the presence of a haustorium or haustoria, host specificity is likely high or more strict. Host recognition mechanisms, which are necessary for spore germination and subsequent penetration of the integument, may be affected or even blocked when ascospores land on a host other than the main host. In contrast, in the absence of haustoria, there are no such developmental barriers and transmitted ascospores can develop on different and even unusual host taxa given these co-occur in a particular microhabitat. Xenotransmission is thought rare in nature because of strict habitat choices of hosts, but we can force development of thalli on unusual hosts under the right conditions in the laboratory (De Kesel 1996a, b) and there are a few examples from the field (De Kesel and Haelewaters 2014; Pfliegler et al. 2016; Reboleira et al. 2017). For non-haustorial Laboulbeniales the potential host range is probably wider than the natural host range; occasional hosts (Nebenwirten) and accidental hosts (Zufallswirten) have been recognized for certain taxa of Laboulbeniales. These are the result of fortuitous encounters when the main host species has overlapping niches with other arthropods occurring in the same microhabitat (Scheloske 1969). Since ascospores are not airborne (Huldén 1983) nor long-lived (De Kesel 1996a, b), direct transmission by contact is a key factor here. For example, some species of Clivina (family Carabidae, subfamily Scaritinae) serve as accidental hosts for Laboulbenia anoplogenii after encountering the parasite's typical hosts, which are beetles in subfamilies Harpalinae and Pterostichinae (Santamaría 1998). The fungus may not persist on these alternative hosts, but accidental transmission probably 

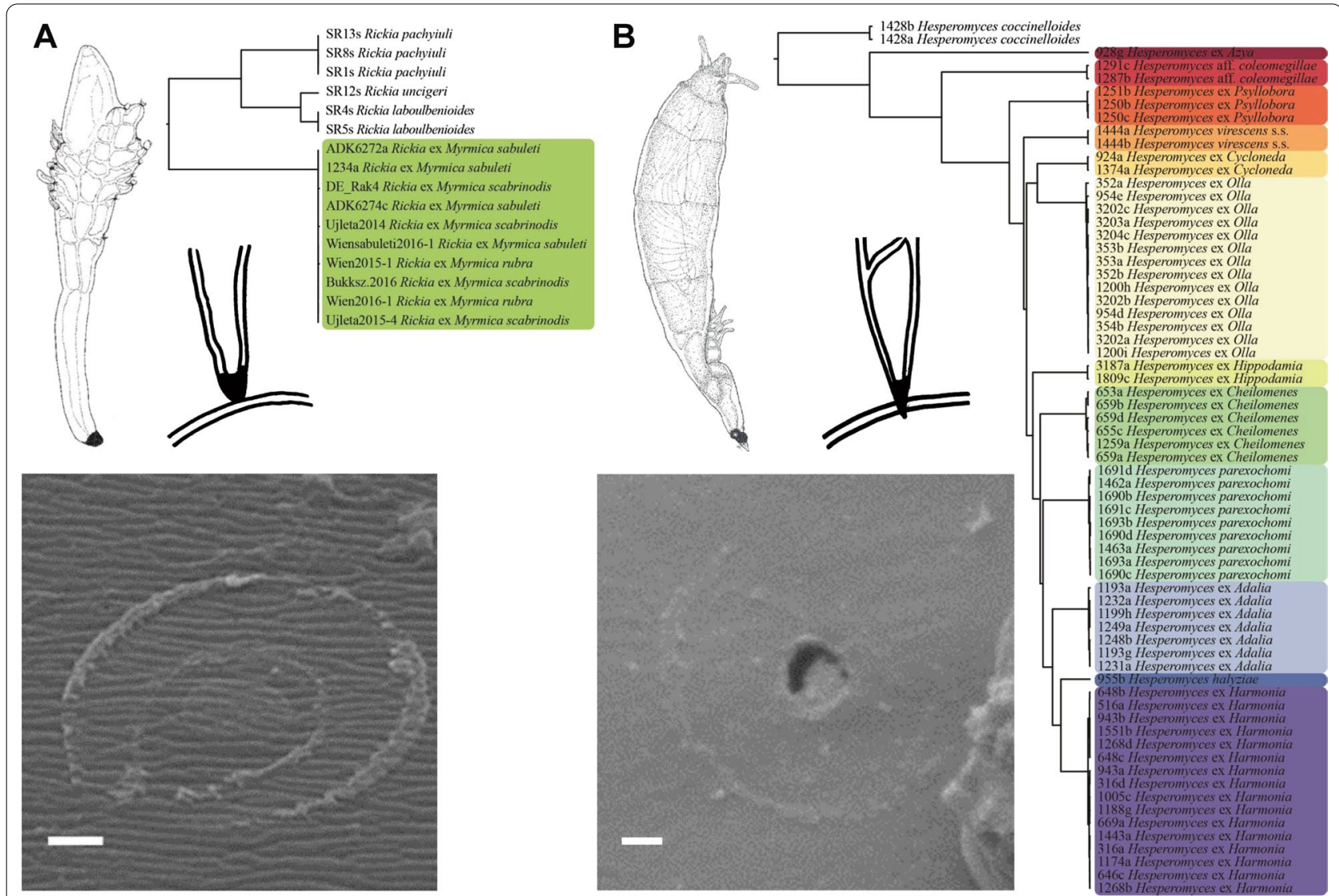

Fig. 1 Visualization of the proposed One-Host-One-Parasite model. A. Rickia wasmannii, a single phylogenetic species with Myrmica hosts in phylogenetically unrelated species groups; no penetration through the host's integument into the haemocoel; and a horseshoe-shaped imprint around a circular inner ring at the otherwise unaffected host integument (scanning electron micrograph, from J. Billen, X. Espadaler, A. Tartally, and S. Tragust). B. Hesperomyces virescens, a complex of multiple species, each species corresponding to a phylogenetic clade with isolates from thalli removed from a given host; penetration through the integument; and a circular 1- $\mu \mathrm{m}$ diameter penetration pore (scanning electron micrograph, from M. Lubbers). Bars $=1 \mu \mathrm{m}$. Color schemes for monophyletic clades from https://colorbrewer2.org by C.A. Brewer, Geography, Pennsylvania State University

has played an important role in speciation processes of Laboulbeniales (Rossi 2011; De Kesel and Haelewaters 2014). Since successful development of a fungus population on its natural host is determined by the habitat (De Kesel 1996a, b), radiation of non-haustorial Laboulbeniales is entirely governed by the habitat choice of any host on which ascospores land.

We suggest that losing the need for an haustorium, created opportunities for Laboulbeniales to shift more easily towards hosts occupying the same or a similar, suitable habitat. This change allowed them to radiate into megadiverse host groups such as Carabidae and Staphylinidae. Abandoning the haustorium has widened the parasite's host range and provided opportunities for radiation, probably forcing the evolution of alternative nutrient uptake mechanisms.

Early on in the studies of Laboulbeniales, Cavara (1899) proposed that thalli might receive nutrients and water from the environment by absorption through their (sterile) appendages. Since many species of Laboulbeniales lack appendages, this claim had long been rejected, until results from experimental work supported Cavara's suggestion (De Kesel 1997). Since we now know that at least some species of Laboulbeniales definitely have no haustorium (Tragust et al. 2016; Reboleira et al. 2021), alternative explanations regarding Laboulbeniales nutrition are needed. We suggest that non-haustorial Laboulbeniales take up waxy lipids as nutrients produced by the host (Tavares 1985; Stanley and Nelson 1993). Such lipid transfers have been shown in the arbuscular mycorrhizal Glomeromycota, which take up fatty acids containing lipids from plant roots (Keymer and Gutjhar 2018). 


\section{FUTURE RESEARCH}

Experimental work should be directed towards investigating nutrient uptake mechanisms in Laboulbeniales. Three alternative methods could be employed:

(1) The use of fluorescence-labeled waxy lipids to monitor waxy lipid uptake into the non-haustorial Laboulbeniales cells. As it has only been hypothesized that non-haustorial Laboulbeniales take up lipids from the arthropod integument, it remains uncertain which type(s) of lipids this could be. A selection of waxy lipids could therefore be fluorescently labeled with BODIPY (Wang et al. 2018). BODIPY has already been used for various pathogenic organisms such as the pathogenic rice fungus Magnaporthe oryzae (Wang et al. 2018) and the parasitic worm Schistosoma mansoni (Furlong et al. 1995). Living insect specimens with thalli of Laboulbenia would need to be collected in the field and bred under laboratory conditions. The site of infection, around the point of contact, should be treated with fluorescently labeled waxy lipids. Fluorescent signals in the thallus cells can then be observed using confocal fluorescence microscopy.

(2) Non-labeled waxy lipids could be investigated in cells of Laboulbeniales with a lipidomics approach (Wenk 2006). Using techniques such as mass spectrometry, various lipids can be detected and characterized. Both host as well as Laboulbeniales cells should be profiled for waxy lipids. If there is a significant similarity between these profiles, this could indicate waxy lipid uptake by the fungus.

(3) The use of stable isotope labeling to monitor lipid uptake by Laboulbeniales cells. Previous experiments with protozoan parasites have shown that ${ }^{13} \mathrm{C}$-labeled precursors (glucose, amino acids, fatty acids) can be taken up by host cells (Kloehn et al. 2016). Whether these labeled metabolites are taken up by the parasite can be detected through liquid chromatography-mass spectrometry (LC/MS), allowing researchers to identify active parasite pathways in vivo (Kloehn et al. 2016). Applying this methodology to Laboulbeniales, we suggest feeding arthropod hosts on a diet of ${ }^{13} \mathrm{C}$-labeled precursors. If the basal-most receptacle cells (especially the foot cell) of Laboulbeniales show presence of ${ }^{13} \mathrm{C}$-labeled molecules with LC/MS detection, this could prove the uptake of specific molecules by the fungus. One should prevent spillage of ${ }^{13} \mathrm{C}$ labeled food by the beetle (via grooming via the mouth parts), otherwise the thallus may directly get in contact with this food and take up ${ }^{13} \mathrm{C}$ directly via its highly absorbing appendages.

Previous research has shown that limited transmission is possible in (haustorial) Hesperomyces virescens between different host species (Cottrell and Riddick 2012). One could suggest this contradicts our 1H1P hypothesis. However, interspecific transmission has only been observed for C. septempunctata, while not for the three other host species tested (Cottrell and Riddick 2012). We believe habitat specificity may allow for transmission, as the hosts were bred in a micro-habitat for an extended time. If separated, these interspecific transmissions could either be ecological dead-ends or result in reproductive isolation over time. This should be tested in long-term multigenerational experiments, with Hesperomyces virescens as the model organism.

\section{CONCLUDING REMARKS}

Recent work with thallus-forming Laboulbeniomycetes has shown that the field is faced with multiple challenges. These range from understanding patterns of speciation to unexplored territories such as exploring the function of the sterile appendages of non-haustorial Laboulbeniales. If one thing has become increasingly clear, it is that morphology alone is not sufficient to draw accurate species limits, due to the existence of near-cryptic species (Crous et al. 2021) and species of which the morphology is affected by the position they occupy on the host integument (Haelewaters and Pfister 2019; Sundberg et al. 2021). Rather, an integrative approach, combining data from multiple sources, is necessary in fungal taxonomy (Cao et al. 2021; Maharachchikumbura et al. 2021), more specifically the taxonomy of Herpomycetales and Laboulbeniales (e.g., Goldmann and Weir 2012; Goldmann et al. 2013; Haelewaters et al. 2018, 2019a, b, c; Sundberg et al. 2018b, 2021; Haelewaters and Pfister 2019; Gutierrez et al. 2020). For this reason, we propose to accompany descriptions of new taxa at all ranks with independent lines of evidence from morphology, DNA, and ecology (host associations). This is in line with the most recent best-practice advocated by the International Commission on the Taxonomy of Fungi (ICTF) on how to describe new fungal species (Aime et al. 2021).

In aiming to understand how speciation in thallusforming Laboulbeniomycetes is mediated, we have hypothesized here that the presence or absence of haustoria is a determining factor. In the presence of a haustorium or multiple haustoria, this automatically leads to the 1H1P model. As for non-haustorial Laboulbeniales, there is no doubt that thallus development depends on both host and habitat. Whereas opportunities for host shifting and radiation increase when different host species share the same microhabitat, successful transmission is contingent upon the nature of the ascospores (not airborne, short-lived; Huldén 1983; De Kesel 1996a, b). The ascospores of all Laboulbeniomycetes are uniform throughout the group-always single-septate (although the position of the septum may differ) and built to stick. This guarantees that ascospore transmission between 
infected and uninfected hosts is highly promoted by direct, mostly intra-specific contact. Studies in specificity and host shifting of Laboulbeniales should also focus on various aspects of transmission, an important bottleneck, especially in situations where hosts are forced to move among habitats because of climate change and human influences (Carlson et al. 2020). Changes in the distribution range of the hosts may affect transmission patterns. To fully understand transmission, we cannot at this point exclude infections to occur through asexual or free-living stages. To be able to detect these stages of Laboulbeniales in environmental next-generation sequencing data, we recommend laboulbeniologists to generate curated sequences of Laboulbeniales and make them public. Only recently, a clade containing both genera known only as asexual morphs (Chantransiopsis and Tetrameronycha) and ones only known as sexual morphs (Subbaromyces) was revealed in the class based on molecular phylogenetic analyses (Goldmann and Weir 2018; Blackwell et al. 2020). By increased sampling of fresh material and generating new sequences, it would be no surprise that many more major discoveries will be made in coming yearshopefully shedding more light to this group of enigmatic fungi.

\section{Abbreviations}

1H1P: One-Host-One-Parasite model; ${ }^{13} \mathrm{C}$ : Carbon-13; BODIPY: Boron dipyrromethene; ICTF: International Commission on the Taxonomy of Fungi; LC/MS: Liquid chromatography-mass spectrometry.

\section{Acknowledgements}

The authors are grateful to Meredith Blackwell (Louisiana State University), David L. Hawksworth (Royal Botanic Gardens, Kew \& The Natural History Museum), and five anonymous reviewers for comments and suggestions that considerably improved the manuscript. In addition, discussions during an EcoLunch Seminar of the Department of Biological Sciences and an invited seminar at the Department of Entomology, both at Purdue University (West Lafayette, Indiana), helped develop the here proposed hypothesis.

\section{Authors' contributions \\ Conceptualization, Writing_-original draft preparation: D.H. and A.D.K. Resources: D.H., M.L., and A.D.K. Visualization: M.L. Funding acquisition, Super- vision: D.H. Writing — review and editing: D.H. and M.L. All authors read and approved the final manuscript.}

\section{Funding}

D.H. is a Junior Postdoctoral Fellow supported by the Research Foundation-Flanders (1206620N) and received additional funding from a SYNTHESYS + grant (no. BE-TAF-151), financed by the Horizon 2020 Research Infrastructures Programme of the European Commission.

\section{Availability of data and material \\ Not applicable.}

\section{Declarations}

Ethics approval and consent to participate

Not applicable.

\section{Adherence to national and international regulations} Not applicable.

\section{Consent for publication}

Not applicable.

\section{Competing interests}

The authors declare they have no competing interests.

\section{Author details}

${ }^{1}$ Faculty of Science, University of South Bohemia, Branisovska 31, 35007 České Budějovice, Czech Republic. ${ }^{2}$ Research Group Mycology, Department of Biology, Ghent University, K.L. Ledeganckstraat 35, 9000 Ghent, Belgium. ${ }^{3}$ Harvard University Herbaria, 22 Divinity Avenue, Cambridge, MA 02138, USA. ${ }^{4}$ Institute of Biology Leiden, Leiden University, Sylviusweg 72, 2333 BE Leiden, The Netherlands. ${ }^{5}$ Meise Botanic Garden, Nieuwelaan 38, 1860 Meise, Belgium.

Received: 26 July 2021 Accepted: 19 December 2021

Published online: 31 January 2022

\section{References}

Accioly T, Sousa JO, Moreau PA, Lécuru C, Silva BD, Roy M, Gardes M, Baseia IG, Martín MP (2019) Hidden fungal diversity from the Neotropics: Geastrum hirsutum, G. schweinitzii (Basidiomycota, Geastrales) and their allies. PLoS ONE 14(2):e0211388. https://doi.org/10.1371/journal.pone.0211388

Aime MC, Miller AN, Aoki T, Bensch K, Cai L, Crous PW, Hawksworth DL, Hyde KD, Kirk PM, Lücking R, May TW, Malosso E, Redhead SA, Rossman AY, Stadler M, Thines M, Yurkov AM, Zhang N, Schoch CL (2021) How to publish a new fungal species, or name, version 3.0. IMA Fungus 12(1):11. https://doi.org/10.1186/s43008-021-00063-1

Araújo JPM, Evans HC, Kepler R, Hughes DP (2018) Zombie- ant fungi across continents: 15 new species and new combinations within Ophiocordyceps. I. Myrmecophilous hirsutelloid species. Stud Mycol 90:119-160. https://doi.org/10.1016/j.simyco.2017.12.002

Benjamin RK (1971) Introduction and supplement to Roland Thaxter's contribution towards a monograph of the Laboulbeniaceae. Bibl Mycol 30:1-155

Benjamin RK, Shanor L (1952) Sex of host specificity and position specificity of certain species of Laboulbenia on Bembidion picipes. Am J Bot 39(2):125131. https://doi.org/10.1002/j.1537-2197.1952.tb14255.x

Blackwell M, Malloch D (1989) Pyxidiophora: Life histories and arthropod associations of two species. Can J Bot 67(9):2552-2562. https://doi.org/ 10.1139/b89-330

Blackwell M, Bridges JR, Moser JC, Perry TJ (1986a) Hyperphoretic dispersal of a Pyxidiophora anamorph. Science 232(4753):993-995. https://doi.org/10, 1126/science.232.4753.993

Blackwell M, Perry TJ, Bridges JR, Moser JC (1986b) A new species of Pyxidiophora and its Thaxteriola anamorph. Mycologia 78(4):607-614. https:// doi.org/10.2307/3807773

Blackwell M, Haelewaters D, Pfister DH (2020) Evolution, natural history, and Thaxter's final word. Mycologia 112(6):1048-1059. https://doi.org/10. 1080/00275514.2020.1718442

Cao B, Haelewaters D, Schoutteten N, Begerow D, Boekhout T, Giachini AJ, Gorjón SP, Gunde-Cimerman N, Hyde KD, Kemler M, Li GJ, Liu DM, Liu XZ, Nuytinck J, Papp V, Savchenko A, Savchenko K, Tedersoo L, Theelen $B$, Thines M, Tomšovský M, Toome-Heller M, Urón JP, Verbeken A, Vizzini A, Yurkov AM, Zamora JC, Zhao RL (2021) Delimiting species in Basidiomycota: a review. Fungal Divers 109:181-237. https://doi.org/10.1007/ s13225-021-00479-5

Carlson CJ, Hopkins S, Bell KC, Doña J, Godfrey SS, Kwak ML, Lafferty KD, Moir ML, Speer KA, Strona G, Torchin M, Wood CL (2020) A global parasite conservation plan. Biol Cons 250:108596. https://doi.org/10.1016/j.biocon. 2020.108596

Cavara F (1899) Di una nuova Laboulbeniacea Rickia wasmannii nov. gen. e nov. spec. Malpighia 13:173-188

Cottrell TE, Riddick EW (2012) Limited transmission of the ectoparasitic fungus Hesperomyces virescens between lady beetles. Psyche 2012:814378. https://doi.org/10.1155/2012/814378

Crous PW, Osieck ER, Jurjević Ž, Boers J, van Iperen AL, Starink-Willemse M, Dima B, Balashov S, Bulgakov TS, Johnston PR, Morozova OV, Pinruan U, Sommai S, Alvarado P, Decock CA, Lebel T, McMullan-Fisher S, Moreno G, Shivas RG, Zhao L, Abdollahzadeh J, Abrinbana M, Ageev DV, Akhmetova 
G, Alexandrova AV, Altés A, Amaral AGG, Angelini C, Arenas F, Asselman P, Badali F, Baghela A, Bañares A, Barreto RW, Baseia IG, Bellanger JM, BerrafTebbal A, Biketova AYu, Bukharova NV, Burgess TI, Cabero J, Câmara MPS, Cano-Lira JF, Ceryngier P, Chávez R, Cowan D, de Lima AF, de L. Oliveira R, Denman S, Dang QN, dos Santos Vieira WA, Dovana F, Duarte IG, Eichmeier A, Erhard A, Esteve-Raventós F, Fellin A, Ferisin G, Ferreira RJ, Ferrer A, Finy P, Gaya E, Geering ADW, Gil-Durán C, Glässnerová K, Glushakova AM, Gramaje D, Guard FE, Guarnizo AL, Haelewaters D, Halling RE, Hill R, Hirooka Y, Hubka V, Iliushin VA, Ivanova DD, Ivanushkina NE, Jangsantear P, Justo A, Kachalkin AV, Kato S, Khamsuntorn P, Kirtsideli IY, Knapp DG, Kochkina GA, Koukol O, Kovács GM, Kruse J, Kumar TKA, Kušan I, Læssøe T, Larsson E, Lebel T, Lebeuf R, Levicán G, Loizides M, Lúcio PSM, Luangsaard JJ, Lukina EG, Magaña-Dueñas V, Maggs-Kölling G, Malysheva EF, Malysheva VF, Martín B, Martín MP, Matočec N, McTaggart AR, MehrabiKoushki M, Mešić A, Miller AN, Mironova P, Moreau PA, Morte A, Müller K, Nagy LG, Nanu S, Navarro-Ródenas A, Nel W, Nguyen TH, Nóbrega TF, Noordeloos ME, Olariaga I, Overton BE, Ozerskaya SM, Palani P, Pancorbo F, Papp V, Pawłowska J, Pham TQ, Phosri C, Pichai S, Popov ES, Portugal A, Pošta A, Reschke K, Reul M, Ricci GM, Rodríguez A, Romanowski J, Ruchikachorn N, Saar I, Safi A, Sakolrak B, Salzmann F, Sandoval-Denis M, Sangwichein E, Sanhueza L, Sato T, Sastoque A, Senn-Irlet B, Shibata A, Siepe K, Somrithipol S, Spetik M, Stchigel AM, Stuskova K, Suwannasai N, Tan YP, Thangavel R, Tiago I, Tiwari S, Tkalčec Z, Tomashevskaya MA, Tonegawa C, Tran HX, Tran NT, Trovão J, Trubitsyn VE, Van Wyk J, Vila J, Visagie CM, Vizzini A, Volobuev SV, Vu DT, Wangsawat N, Yaguchi T, Ferreira BW, de Souza AP, Vieira BS, Groenewald JZ. 2021. Fungal Planet description sheets: 1284-1382. Persoonia 47:178-374. https://doi.org/10.3767/perso onia.2021.47.06

De Kesel A (1996a) Relative importance of direct and indirect infection in the transmission of Laboulbenia slackensis (ascomycetes, Laboulbeniales). Belg J Bot 128(2):124-130

De Kesel A (1996b) Host specificity and habitat preference of Laboulbenia slackensis. Mycologia 88(4):565-573. https://doi.org/10.1080/00275514. 1996.12026687

De Kesel A (1997) Contribution towards the study of the specificity of Laboulbeniales (Fungi, ascomycetes), with particular reference to the transmission, habitat preference and host-range of Laboulbenia slackensis. Ph.D. dissertation. University of Antwerp, Antwerp. https://doi.org/10.2307/ 3761150

De Kesel A (1998) Identification and host-range of the genus Laboulbenia in Belgium. Sterbeeckia 18:13-31

De Kesel A, Haelewaters D (2014) Laboulbenia slackensis and L. littoralis sp. nov (Ascomycota, Laboulbeniales), two sibling species as a result of ecological speciation. Mycologia 106(3):407-414. https://doi.org/10.3852/13-348

de Queiroz K (1998) The general lineage concept of species, species criteria, and the process of speciation: a conceptual unification and terminological recommendations. In: Howard DJ, Berlocher SH (eds) Endless forms. Species and speciation. Oxford University Press, Oxford, pp 57-75

de Queiroz K (2007) Species concepts and species delimitation. Syst Biol 56(6):879-886. https://doi.org/10.1080/10635150701701083

Dobzhansky T (1946) Complete reproductive isolation between two morphologically similar species of Drosophila. Ecology 27(3):205-211. https://doi. org/10.2307/1932895

Ehrlich PR, Raven PA (1964) Butterflies and plants: a study in coevolution. Evolution 18(4):586-608. https://doi.org/10.1111/j.1558-5646.1964.tb01674.x

Furlong ST, Thibault KS, Morbelli LM, Quinn JJ, Rogers RA (1995) Uptake and compartmentalization of fluorescent lipid analogs in larval Schistosoma mansoni. J Lipid Res 36(1):1-12. https://doi.org/10.1016/S0022-2275(20) 39749-2

Goldmann L, Weir A (2012) Position specificity in Chitonomyces (Ascomycota, Laboulbeniomycetes) on Laccophilus (Coleoptera, Dytiscidae): a molecular approach resolves a century-old debate. Mycologia 104(5):1143-1158. https://doi.org/10.3852/11-358

Goldmann L, Weir A (2018) Molecular phylogeny of the Laboulbeniomycetes (Ascomycota). Fungal Biol 122(2-3):87-100. https://doi.org/10.1016/j. funbio.2017.11.004

Goldmann L, Weir A, Rossi W (2013) Molecular analysis reveals two new dimorphic species of Hesperomyces (Ascomycota, Laboulbeniomycetes) parasitic on the ladybird Coleomegilla maculata (Coleoptera, Coccinellidae). Fungal Biol 117(11-12):807-813. https://doi.org/10.1016/j.funbio.2013.10.004
Grünig CR, Duo A, Sieber TN, Holdenrieder O (2008) Assignment of species rank to six reproductively isolated cryptic species of the Phialocephala fortinii s.l.-Acephala applanata species complex. Mycologia 100(1):47-67. https://doi.org/10.1080/15572536.2008.11832498

Gutierrez AC, Ordoqui E, Leclerque A, López Lastra C (2020) A new species of Herpomyces (Laboulbeniomycetes: Herpomycetales) on Periplaneta fuliginosa (Blattodea: Blattidae) from Argentina. Mycologia 112(6):1184-1191. https://doi.org/10.1080/00275514.2020.1726134

Haelewaters D, De Kesel A (2020) Checklist of thallus-forming Laboulbeniomycetes from Belgium and the Netherlands, including Hesperomyces halyziae and Laboulbenia quarantenae spp. nov. MycoKeys 71:23-86. https://doi. org/10.3897/mycokeys.71.53421

Haelewaters D, Pfister DH (2019) Morphological species of Gloeandromyces (Ascomycota, Laboulbeniales) evaluated using single-locus species delimitation methods. Fungal Syst Evol 3:19-33. https://doi.org/10.3114/ fuse.2019.03.03

Haelewaters D, Gorczak M, Pfliegler WP, Tartally A, Tischer M, Wrzosek M, Pfister DH (2015) Bringing Laboulbeniales into the 21st century: enhanced techniques for extraction and PCR amplification of DNA from minute ectoparasitic fungi. IMA Fungus 6(2):363-372. https://doi.org/10.5598/ imafungus.2015.06.02.08

Haelewaters D, De Kesel A, Pfister DH (2018) Integrative taxonomy reveals hidden species within a common fungal parasite of ladybirds. Sci Rep 8(1):15966. https://doi.org/10.1038/s41598-018-34319-5

Haelewaters D, Boer P, Báthori F, Rádai Z, Reboleira ASP, Tartally A, Pfiegler W, De Kesel A, Nedvěd O (2019a) Studies of Laboulbeniales on Myrmica ants (IV): host-related diversity and thallus distribution patterns of Rickia wasmannii. Parasite 26:29. https://doi.org/10.1051/parasite/2019028

Haelewaters D, Pfliegler WP, Gorczak M, Pfister DH (2019b) Birth of an order: Comprehensive molecular phylogenetic study excludes Herpomyces (Fungi, Laboulbeniomycetes) from Laboulbeniales. Mol Phylogenet Evol 133:286-301. https://doi.org/10.1016/j.ympev.2019.01.007

Haelewaters D, Zhao SY, De Kesel A, Handlin RE, Royer IR, Farrell BD, Pfister DH (2019c) Laboulbeniales (Ascomycota) of the Boston Harbor Islands II: species parasitizing Carabidae, and the Laboulbenia flagellata species complex. Northeast Nat 25(Special Issue 9):110-149. https://doi.org/10. 1656/045.025.s906

Haelewaters D, Gorczak M, Kaishian P, De Kesel A, Blackwell M (2021a) Laboulbeniomycetes, enigmatic fungi with a turbulent taxonomic history. In: Zaragoza Ó (ed) Encyclopedia of mycology, vol 1. Elsevier, Oxford, pp 263-283. https://doi.org/10.1016/B978-0-12-819990-9.00049-4

Haelewaters D, Schoutteten N, Medina-van Berkum P, Martin TE, Verbeken A, Aime MC (2021b) Pioneering a fungal inventory at Cusuco National Park, Honduras. J Mesoam Biol 1(1):111-131

Hawksworth DL, Rossman AY (1997) Where are all the undescribed fungi? Phytopathology 87(9):888-891. https://doi.org/10.1094/PHYTO.1997.87.9.888

Huldén L (1983) Laboulbeniales (ascomycetes) of Finland and adjacent parts of the U.S.S.R. Karstenia 23:31-136. https://doi.org/10.29203/ka.1983.221

Jacobs K, Holtzman K, Seifert KA (2005) Phylogeny and biology of Gliocephalis hyalina, a biotrophic contact mycoparasite of Fusarium species. Mycologia 97(1):111-120. https://doi.org/10.1080/15572536.2006.11832844

Keymer A, Gutjhar C (2018) Cross-kingdom lipid transfer in arbuscular mycorrhiza symbiosis and beyond. Curr Opin Plant Biol 44:137-144. https://doi. org/10.1016/j.pbi.2018.04.005

Kirschner R (2003) Two new species of Pyxidiophora associated with bark beetles in Europe. Mycol Prog 2(3):209-218. https://doi.org/10.1007/ s11557-006-0058-z

Kloehn J, Blume M, Cobbold SA, Saunders EC, Dagley MJ, McConville MJ (2016) Using metabolomics to dissect host-parasite interactions. Curr Opin Microbiol 32:59-65. https://doi.org/10.1016/j.mib.2016.04.019

Konrad M, Grasse AV, Tragust S, Cremer S (2015) Anti-pathogen protection versus survival costs mediated by an ectosymbiont in an ant host. Proc $R$ Soc B 282(1799):20141976

Li YM, Shivas RG, Cai L (2017) Cryptic diversity in Tranzscheliella spp. (Ustilaginales) is driven by host switches. Sci Rep 7(1):43549. https://doi.org/10. 1038/srep43549

Lundqvist N (1980) On the genus Pyxidiophora sensu lato (pyrenomycetes). Bot Notiser 133:121-144

Maharachchikumbura SSN, Chen Y, Ariyawansa HA, Hyde KD, Haelewaters D, Perera RH, Samarakoon MC, Wanasinghe DN, Bustamante DE, Liu J-K, Lawrence DP, Cheewangkoon R, Stadler M (2021) Integrative approaches 
for species delimitation in Ascomycota. Fungal Divers 109:155-179. https://doi.org/10.1007/s13225-021-00486-6

Pfliegler WP, Báthori F, Haelewaters D, Tartally A (2016) Studies of Laboulbeniales on Myrmica ants (III): myrmecophilous arthropods as alternative hosts of Rickia wasmannii. Parasite 23:50. https://doi.org/10.1051/paras ite/2016060

Pringle A, Baker DM, Platt JL, Wares JP, Latge JP, Taylor JW (2005) Cryptic speciation in the cosmopolitan and clonal human pathogenic fungus Aspergillus fumigatus. Evolution 59(9):1886-1899. https://doi.org/10, 1111/j.0014-3820.2005.tb01059.x

Reboleira ASP, Fresnada J, Salgado JM (2017) A new species of Speonemadus from Portugal, with the revision of the escalerai-group (Coleoptera, Leiodidae). Eur J Taxon 261:1-23. https://doi.org/10.5852/ejt.2017.261

Reboleira ASPS, Moritz L, Santamaria S, Enghofff H (2021) Penetrative and nonpenetrative interaction between Laboulbeniales fungi and their arthropod hosts. Sci Rep 11:22170. https://doi.org/10.1038/s41598-021-01729-x

Richards AG, Smith MN (1954) Infection of cockroaches with Herpomyces (Laboulbeniales). III. Experimental studies on host specificity. Bot Gazette 116(2):195-198. https://doi.org/10.1086/335861

Rossi W (2011) New species of Laboulbenia from Ecuador, with evidence for host switch in the Laboulbeniales. Mycologia 103(1):184-194. https://doi. org/10.3852/10-117

Santamaría S (1998) Laboulbeniales, I. Laboulbenia. Flora Mycol Iber 4:1-186

Scheloske HW (1969) Beiträge zur Biologie, Ökologie und Systematik der Laboulbeniales (Ascomycetes) unter besondere Berücksichtigung des Parasit-Wirt-Verhältnisses. Parasitol Schriftenr 19:1-176

Scheloske HW (1976) Eusynaptomyces benjaminii, spec. nova, (Ascomycetes, Laboulbeniales) und seinde Anpassungen an das Fortpflanzungsverhalten seines Wirtes Enochrus testaceus (Coleoptera, Hydrophilidae). Plant Syst Evol 126(3):267-285. https://doi.org/10.1007/BF00983366

Singh G, Dal Grande F, Divakar PK, Otte J, Leavitt SD, Szczepanska K, Crespo A, Rico VJ, Aptroot A, da Silva Cáceres ME, Lumbsch HT, Schmitt I (2015) Coalescent-based species delimitation approach uncovers high cryptic diversity in the cosmopolitan lichen-forming fungal genus Protoparmelia (Lecanorales, Ascomycota). PLoS ONE 10(5):e0124625. https://doi.org/10. 1371/journal.pone.0124625

Skrede I, Carlsen T, Schumacher T (2017) A synopsis of the saddle fungi (Helvella: Ascomycota) in Europe-species delimitation, taxonomy and typification. Persoonia 39:201-253. https://doi.org/10.3767/persoonia. 2017.39.09

Sochorová Z, Döbbeler P, Sochor M, van Rooy J (2019) Octospora conidiophora (Pyronemataceae) - a new species from South Africa and the first report of anamorph in bryophilous Pezizales. MycoKeys 54:49-76. https://doi. org/10.3897/mycokeys.54.34571

Stanley DW, Nelson DR (1993) Insect lipids: chemistry, biochemistry, and biology. University of Nebraska Press, Lincoln

Stefani FO, Jones RH, May TW (2014) Concordance of seven gene genealogies compared to phenotypic data reveals multiple cryptic species in Australian dermocyboid Cortinarius (Agaricales). Mol Phylogenet Evol 71:249-260. https://doi.org/10.1016/j.ympev.2013.10.019

Sundberg H, Ekman S, Kruys $\AA$ (2018a) A crush on small fungi: an efficient and quick method for obtaining DNA from minute ascomycetes. Methods Ecol Evol 9(1):148-158. https://doi.org/10.1111/2041-210X.12850

Sundberg H, Kruys Å, Bergsten J, Ekman S (2018b) Position specificity in the genus Coreomyces (Laboulbeniomycetes, Ascomycota). Fungal Syst Evolut 1:217-228. https://doi.org/10.3114/fuse.2018.01.09

Sundberg H, Kruys $\AA$, Bergsten J, Ekman S (2021) Coreomyces (Laboulbeniales) in Sweden, with two new species. Nord J Bot 39(11):e03323. https://doi. org/10.1111/njb.03323

Tavares II (1985) Laboulbeniales (Fungi, Ascomycetes). Mycol Mem 9:1-627

Thaxter R (1896) Contribution towards a monograph of the Laboulbeniaceae. Mem Am Acad Arts Sci 12(3):187-429

Thaxter R (1931) Contribution towards a monograph of the Laboulbeniaceae. Part V. Mem Am Acad Arts Sci 16:1-435

Tragust S, Tartally A, Espadaler X, Billen J (2016) Histopathology of Laboulbeniales (Ascomycota: Laboulbeniales): ectoparasitic fungi on ants (Hymenoptera: Formicidae). Myrmecol News 23:81-89

Wang TW, de Kesel A, Haelewaters D, Pfister DH (2016) Farlow Herbarium cockroach hosts new record of Laboulbeniales for North America. Rhodora 118(973):26-31. https://doi.org/10.3119/15-20
Wang J, Guo X, Li L, Qiu H, Zhang Z, Wang Y, Sun G (2018) Application of the fluorescent dye BODIPY in the study of lipid dynamics of the rice blast fungus Magnaporthe oryzae. Molecules 23(7):1594. https://doi.org/10. 3390/molecules23071594

Weir A, Blackwell M (2001) Extraction and PCR amplification of DNA from minute ectoparasitic fungi. Mycologia 93(4):802-806. https://doi.org/10 2307/3761835

Weir A, Hammond PM (1997) Laboulbeniales on beetles: host utilization patterns and species richness of the parasites. Biodivers Conserv 6(5):701719. https://doi.org/10.1023/A:1018318320019

Wenk MR (2006) Lipidomics of host-pathogen interactions. FEBS Lett 580(23):5541-5551. https://doi.org/10.1016/j.febslet.2006.07.007

Wijayawardene NN (2019) The necessity of working with "orphaned" asexual genera. Ser Mycol Microbiol 1:1-3

Yin M, Wingfield MJ, Zhou X, Linnakoski R, De Beer ZW (2019) Taxonomy and phylogeny of the Leptographium olivaceum complex (Ophiostomatales, Ascomycota), including descriptions of six new species from China and Europe. MycoKeys 60:93-123. https://doi.org/10.3897/mycokeys.60. 39069

\section{Publisher's Note}

Springer Nature remains neutral with regard to jurisdictional claims in published maps and institutional affiliations.

Ready to submit your research? Choose BMC and benefit from

- fast, convenient online submission

- thorough peer review by experienced researchers in your field

- rapid publication on acceptance

- support for research data, including large and complex data types

- gold Open Access which fosters wider collaboration and increased citations

- maximum visibility for your research: over 100M website views per year

At BMC, research is always in progress.

Learn more biomedcentral.com/submissions 